\title{
Real Options: An Evaluation Tool for a Photovoltaic System for Self-consumption
}

\author{
Joana Fialho, Pedro Pinto, Ana Lúcia Gomes \\ Center for Studies in Education, Technologies and Health, Polytechnic Institute of Viseu, Viseu, Portugal \\ Email address: \\ jfialho@estgv.ipv.pt(J.Fialho),spinto@estgv.ipv.pt(P. Pinto), anagomesfcp@hotmail.com (A. L. Gomes)
}

To cite this article:

Joana Fialho, Pedro Pinto, Ana Lúcia Gomes. Real Options: An Evaluation Tool for a Photovoltaic System for Self-consumption. International Journal of Energy and Power Engineering. Vol. 7, No. 5, 2018, pp. 59-66. doi: 10.11648/j.ijepe.20180705.12

Received: October 17, 2018; Accepted: November 1, 2018; Published: December 14, 2018

\begin{abstract}
The use of renewable sources to produce energy is good for the planet and has economic value, that is, investing in the produce of green energy can be economically viable. This paper aims to conduct an evaluation, using real options tools, of a photovoltaic (PV) system, for self-consumption, at the Campus of Polytechnic Institute of Viseu, Portugal. A PV system produces electricity from sun and its investment can be viable, particularly in sunny countries like Portugal. This viability comes from the rapid recovery of the investment, since the energy produced is no longer bought to the electrical network. The utilization of real options, in this study, namely the decision trees, allows integrating uncertainty sources and operational flexibility. In this work, we considered the price of electricity tariff and the value of the initial investment as uncertain values. The operational flexibility is integrated by considering the options "invest", "defer" and "not invest" in the PV system, for selfconsumption. The results suggest that the Polytechnic Institute of Viseu should invest in a PV system, for self-consumption. The use of solar energy, especially in countries with high sun expose, such as Portugal, is economically viable.
\end{abstract}

Keywords: Real Options, Decision Trees, Photovoltaic System, Self-consumption, Energetic Sustainability

\section{Introduction}

Global warming and its environmental consequences on the planet have led to increased energy production from renewable or clean sources. Energy production using renewable resources has been supported by governmental policies, in different countries. One of these sources is the sun, which allows, among others, producing electricity - photovoltaic solar energy. Portugal is a country with a high number of hours of sun exposure and has a system of incentives to produce energy with low environmental impact. The interest in this type of investment stems from the rapid recovery of investment and from the technology used that provides low maintenance costs [1]. Mathews and Mathews [2] studied the financial feasibility of different configurations of solar photovoltaic energy for a consumer's household. They concluded that these investments are viable with good payback periods.

In order to increase photovoltaic solar energy, in 2014, in Portugal, legislation about self-consumption was published, encouraging the self-production and consequently, decreasing the electricity acquisition.

This work intends to analyze the investment in a solar photovoltaic (PV) system for self-consumption, in the Polytechnic Campus of the Polytechnic Institute of Viseu, Portugal.

The decision of investing in a PV system can be influenced by factors such as the electricity price and the value of the investment itself. Furthermore, the decision of investment can be deferred because the uncertainty presented, either in the price of the electricity or in the investment value. Towards these aspects, the evaluation of such investment might be into account both flexibility and uncertainty. Thus, the real options theory seems to be useful to carry out this evaluation.

Notice that traditional evaluation methods, such as the ones based on discounted cash flows, like the Net Present Value (NPV), might not be sufficient because they assume a predetermined and fixed plan, which does not allow taking into account both uncertainty and flexibility [3]. In this particular investment, the decision trees were used, since it is a simple real options technique, especially when there are not many uncertain factors nor many decisions to make along project lifetime.

There are other studies using real options to analyze the investment in energy production from renewable sources. For example, Mancini et al. [4] use this technique to determine the viability of investing in energy production from wind and 
from sun.

Beyond this introductory part, this document is organized as follows: section 2 contextualizes the problem of photovoltaic solar energy and reviews some literature about economic evaluation, section 3 describes the methodology and procedures used; section 4 presents the results obtained, and section 5 concludes.

\section{Literature Review}

In this section, the photovoltaic systems and respective Portuguese legislation are, generally, addressed. Next, some real options techniques, namely, the decision trees, are introduced.

\subsection{Photovoltaic Systems and Portuguese Legislation}

Photovoltaic systems allow electricity production, from the sun energy. They are constituted by photovoltaic modules, inverters, wiring and other elements of electrical circuits [1]. Photovoltaic cells form each module, and these cells allow the transformation of solar energy into electrical energy, through the photovoltaic effect [5]. The inverters are devices that convert electric current allow the connection between the photovoltaic generator and the electrical network [5].

The Portuguese Decree-Law no. 153/2014 [6] regulates the units for the production of electricity for self-consumption (UPAC). These units may use renewable or non-renewable energy sources, have a power limit and some production requirements: the installed power system must be less than the contracted power and the total annual energy production should be less than the needs. The energy produced is preferably used for self-consumption, but if the consumption is instantaneously less than the production, the surplus can be sold and injected into the electrical network at a defined sale rate, less $10 \%$ (due to injection expenses). All the characteristics can be consulted in the referred decree-law or, in short, in [7].

In this case study, the UPAC is constituted by a PV system and its economical evaluation is herein performed, using real options techniques.

\subsection{Real Options}

Traditionally, to evaluate a project economically, it is necessary to analyze, over time, operating cash flows and compare them with the investment ones [8]. One of the most used measures is the NPV, which compares the operating cash flows generated by the project with the capital invested. All cash-flows (of exploration and investment, if carried out in different periods) are reported at an initial moment (year 0) with the use of a proper discount rate. The NPV is the difference between the current value of the operating cash flows and the investment cash flows [8]. An investment project is economically viable when it has a positive NPV.

However, these kind of evaluation methods are not adequate to evaluate projects that have operational flexibility (possibility of adapting the plan of action, according to the way the project is developing), because they assume a pre-determined and fixed plan [5]. Furthermore, the realized cash flows will probably be different from what was expected, due to the uncertainty. Real options methods take into account both operational flexibility and uncertainty, aiding the identification of the best decisions. A nice introduction to this theory can be found in [9]. A real option gives the right (but not the obligation) to take a determined action. Its valuation is based on financial options theory and allows assessing investments under uncertainty, because it takes into account the risks and the flexibility value for making decisions when new information arrives [10].

In the valuation of investment projects, real options consider that there is the right but not the obligation to act upon the development process. The evaluation models based on real options emphasize the flexibility and the options available [11]. The recognition that the financial options theory can be used to evaluate investment projects was made by Myers [12], who used the expression real option to express the management flexibility under uncertain environments. Real options theory allows determining the best sequence of decisions to make in an uncertain environment, and provides the proper way to evaluate a project when such flexibility is present. The decisions are made according to the opportunities that appear along the project lifetime, which means that the optimal decision-path is chosen step by step, switching paths as events take place and opportunities appear [13]. The models to evaluate real options can present some difficulties, like determining the model inputs, among others, but following a real options perspective may have a significantly positive impact in the financial performance of a project. Many authors use real options to evaluate $R \& D$ projects in different areas. Brach and Paxson [14], for example, use real options to evaluate pharmaceutical R\&D, Lint and Pennings [15] also use a real options model in the Philips Electronics, Schwartz and Zozaya-Gorostiza [16] use real options in information technology, and Lee and Paxson [17] in e_commerce.

In this study, the incorporation of different options and sequential decisions was done using decision trees, which are one of the real option techniques. In general, decision trees allow modeling decision sequences in the presence of uncertainty. For the different sequences, the value of the project is calculated (through NPV), allowing to select the best combination of decisions. The analysis of a decision tree starts with the leaves and, at each node, the expected value for the project is calculated. The best decision is the one that produces the highest expected value [18]. This technique is very simple and visual, mainly when there are a few uncertainty factors and options, as is the case of this investment.

\section{Methodology}

The Polytechnic Campus of Viseu has a significant cost with energy consumption. In this sense, the economic interest of producing part of the electricity consumed, with a PV system, is analyzed. This study was based on the consumption profile in the year 2015. The Polytechnic Campus is considered a non-residential consumer, whereby the contracted power depends on the maximum power used in the year before.

The power of the UPAC PV system has to be lower than the 
contracted power [6]. A. Gomes et al. [19] analyzed 3 different scenarios for the power of this UPAC system, based on the power contracted by Campus and on the maximum powers recorded. Notice that the increase of the system power leads on an increase of the value of the investment, but, on the other hand, there is an increase of the production of electricity for self-consumption and, therefore, Campus buys less energy from the electrical network. The value of the UPAC investment is defined by $\mathrm{kWp}$ of the power system, i.e., the investment value results from the multiplication between the unit value per $\mathrm{kWp}$ and the value of the UPAC system power.

The electricity produced by the UPAC is self-consumed, but on some instants of the day, the production may be higher than the consumption, and this surplus is injected and sold to the electrical network. The value of the electricity produced by the UPAC constitutes an opportunity cost, since Campus doesn't buy it from the network. This opportunity cost is calculated multiplying the tariff per $\mathrm{kWh}$ and the amount of electricity produced by UPAC. Campus fees are lower than those practiced in the market, due to contractual issues. A. Gomes et al. [19] concluded that, among the values $90 \mathrm{kWp}, 250 \mathrm{kWp}$ and $441 \mathrm{kWp}$, the power of $250 \mathrm{kWp}$ was the most appropriate for this PV system.

In this study, the real options analyzed are "invest", "defer" and "not invest" in the UPAC PV system. The option of investing is influenced by the investment value and by the tariff value, which are considered to be uncertain.

With the use of real options, in particular the decision tree technique, it is intended to assess the economic feasibility of the project and its opportunity.

\section{Results}

Income and expenses were estimated, in order to calculate the cash flows. The cost of the PV system investment, I, is defined per $\mathrm{kWp}$ of the power system and the total investment is obtained multiplying I and the power system. We assume, according with the current market values, that, for $250 \mathrm{kWp}$, the investment value is $1,050 € / \mathrm{kWp}$. Besides the investment, it is necessary to pay a license, which is assumed to be 7,500 €, and the final value, with $23 \%$ VAT (Value Added Tax), is 332,100 €.

The UPAC system produces electricity for self-consumption and the surplus generated (if production exceeds the needs) is injected into network. When the UPAC does not produce the necessary energy, it is necessary to acquire it from the electrical network. The sum of energy produced for selfconsumption with that purchased from the electrical network totals the needs of the Campus in terms of electricity.

The opportunity costs of self-consumption production are calculated from the average electricity tariff, which corresponds to a weighted average and it is calculated taking into account the tetra-hourly tariff (super-empty, empty, full and peak) and the sun exposure (defined as 9 am-5 pm all year). Currently, Campus benefits a bonus on the tariff, since it is a public organization. Assuming this bonus, the average value of the tariff is defined as $0,0756 € / \mathrm{kWh}$ [19]. The number of $\mathrm{kWh}$ produced for self-consumption times the tariff value determines the opportunity cost relative to self-consumption.

In addition to this value, when there are surplus injected into the electrical network, the sale value, per $\mathrm{kWh}$, is defined by auction. According to REN's 2015 annual report (REN is a Portuguese company of transport of electricity and natural gas), this value was $0.0504 € / \mathrm{kWh}$ [20] less $10 \%$, due to legislation [6], which lead to the net value of $0.045 € / \mathrm{kWh}$. The number of $\mathrm{kWh}$ injected into the network times the sale value determines the income obtained from the sale of the surplus produced by UPAC.

There is also an opportunity cost related to the so-called tip hour power, which is defined as the average active power at peak period [21]. During this period, Campus supports not only the price of the electricity, defined by the multiplication between the tariff and the number of $\mathrm{kWh}$ spent, but also an amount relatively to the tip hour power. This amount is calculated, monthly, through the multiplication of a specific tariff $(€ / \mathrm{kWh})$ and the number of the month days and the average power (peak period energy divided by the peak period hours in the month).

The tip period exists, essentially, during the day. Therefore, with UPAC energy production, there is a significant decrease, in this period, in the number of $\mathrm{kWh}$ purchased from the electrical network. The difference between the amount paid for tip hour power without UPAC and with UPAC constitutes other opportunity cost to be considered in the economic evaluation.

Table 1 resumes the worth obtained from UPAC, during the first year of utilization, assuming the immediate investment and that the tariff has the current bonus.

Table 1. UPAC WORTH (VALUES IN EUROS).

\begin{tabular}{lll}
\hline Opportunity Cost & & Network injection \\
\hline Tip hour power & Self-consumption & \\
\hline 12,711 & 27,156 & 1,943 \\
Total $=41,810$ & & \\
\hline
\end{tabular}

UPAC installation and utilization requires a civil liability insurance contract, as well as expenses associated with O\&M. Regardless the system power of UPAC, it is considered an annual insurance of $150 €$. The O\&M annual costs depend on the system power: about $6 € / \mathrm{kW}$ plus $23 \% \mathrm{VAT}$.

Table 2 summarizes the annual expenditures with UPAC use and maintenance.

Table 2. Annual values with UPAC use and maintenance.

\begin{tabular}{llll}
\hline Power System & Insurance price & O\&M & Total \\
\hline$[\mathrm{kWp}]$ & {$[€]$} & {$[€]$} & {$[€]$} \\
250 & 150 & 1,850 & 2,000 \\
\hline
\end{tabular}

Tables 1 and 2 resume UPAC worth and expenditures for the first year of utilization. In the following years, a depreciation of $0.8 \%$ /year is considered in UPAC system [22], due to the solar panels and invertors deterioration. Thus, production decreases annually according to that value, as well as the opportunity costs and the income from the sale of surplus energy. Cash flows are calculated at constant prices and it was considered a discount rate of $6.573 \%{ }^{1}$.

1 Value based on ERSE [21], and determined with Capital Asset Pricing Model (CAPM) 
After 15 years, a continuity value was assumed for the photovoltaic system. The value of continuity represents a perpetuity based on the cash flow of the last year in which we make projections (year 15), and assuming a constant longterm growth rate $(\mathrm{g})$. Thus, the continuity value, $\mathrm{VC}$, is equal to

$$
V C=\frac{C F_{16}}{r-g}
$$

where $C F_{16}$ represents the cash flow in year 16 $\left(\mathrm{CF}_{15} \mathrm{x}(1+\mathrm{g})\right)$. In this case, the growth rate, $\mathrm{g}$, represents the evolution of the photovoltaic system and, therefore, this rate is negative, since the system deteriorates, on average, $0.8 \% /$ year.

Table 3 summarizes the cash flows, the continuity value and the NPV (taking into account the continuity value), assuming the immediate investment and the bonus on the tariff.

Table 3. UPAC values.

\begin{tabular}{lllllll}
\hline Year & Income $[\boldsymbol{\epsilon}]$ & Expenditures $[\boldsymbol{\epsilon}]$ & Cash-Flows $[\boldsymbol{\epsilon}]$ & Pres. coef. & $\begin{array}{l}\text { Present Cash- } \\
\text { Flows }[\boldsymbol{\epsilon}]\end{array}$ & $\begin{array}{l}\text { Cumul. present } \\
\text { Cash-Flows }[\boldsymbol{\epsilon}]\end{array}$ \\
\hline 0 & Investment & & & & $-332,100.00$ & $-332,100.00$ \\
1 & $41,809.73$ & $-2,000.00$ & $39,809.73$ & 1.066 & $37,354.26$ & $-294,745.74$ \\
2 & $41,475.25$ & $-2,000.00$ & $39,475.25$ & 1.136 & $34,755.76$ & $-259,989.97$ \\
3 & $41,143.45$ & $-2,000.00$ & $39,143.45$ & 1.210 & $32,337.91$ & $-227,652.06$ \\
4 & $40,814.30$ & $-2,000.00$ & $38,814.30$ & 1.290 & $30,088.16$ & $-197,563.90$ \\
5 & $40,487.78$ & $-2,000.00$ & $38,487.78$ & 1.375 & $27,994.83$ & $-169,569.07$ \\
6 & $40,163.88$ & $-2,000.00$ & $38,163.88$ & 1.465 & $26,047.04$ & $-143,522.02$ \\
7 & $39,842.57$ & $-2,000.00$ & $37,842.57$ & 1.562 & $24,234.69$ & $-119,287.33$ \\
8 & $39,523.83$ & $-2,000.00$ & $37,523.83$ & 1.664 & $22,548.36$ & $-96,738.96$ \\
9 & $39,207.64$ & $-2,000.00$ & $37,207.64$ & 1.774 & $20,979.30$ & $-75,759.66$ \\
10 & $38,893.98$ & $-2,000.00$ & $36,893.98$ & 1.890 & $19,519.35$ & $-56,240.31$ \\
11 & $38,582.83$ & $-2,000.00$ & $36,582.83$ & 2.014 & $18,160.93$ & $-38,079.38$ \\
12 & $38,274.16$ & $-2,000.00$ & $36,274.16$ & 2.147 & $16,896.99$ & $-21,182.40$ \\
13 & $37,967.97$ & $-2,000.00$ & $35,967.97$ & 2.288 & $15,720.95$ & $-5,461.45$ \\
14 & $37,664,23$ & $-2,000.00$ & $35,664.23$ & 2.438 & $14,626.71$ & $9,165.26$ \\
15 & $37,362.91$ & $-2,000.00$ & $35,362.91$ & 2.599 & $13,608.58$ & $22,773.84$ \\
VC & & & $475,761.32$ & & $183,085.49$ & \\
NPV & $205,859.33$ & & & & &
\end{tabular}

The investment, in this PV system, is economic viable, since it has a positive NPV $(205,859.33 €)$ and has a payback lower than 14 years (necessary time to recover the investment).

The investment on PV systems has been decreasing over the last few years and the tendency is to continue decreasing [24]. Thus, it is considered that the investment can decrease in the following year, with a probability of $80 \%$, and the probability of the investment remains is $20 \%$. If the investment decreases, it is considered a decrement of $15 \%$ in the price of $€ / \mathrm{kWp}$. On the one hand, defer the investment can allow saving part of the investment; but, on the other hand, Campus defer the income obtained from the PV system.

Relatively to the electricity tariff, currently, Campus benefits from low values, since it is a public organization. It is considered that there is a $30 \%$ probability that the Campus will not have this benefit and will support the prices defined by ERSE [25], paying an electricity tariff of $0.1325 € / \mathrm{kWh}$. Also, the price of the tip hour power is modified according to ERSE [25].

The two uncertain factors, above described, are taken into account to analyze the PV system investment, using decision trees. Decision trees model decision sequences in uncertain environments and allow evaluating which the best decisions are. In the representation of a decision tree, the squares represent decision nodes and the circles represent probability nodes.

The decision tree of this investment project is represented in Figure 1. On each leaf of the tree, the NPV is presented. The NPVs calculations are similar to the previous calculations. 


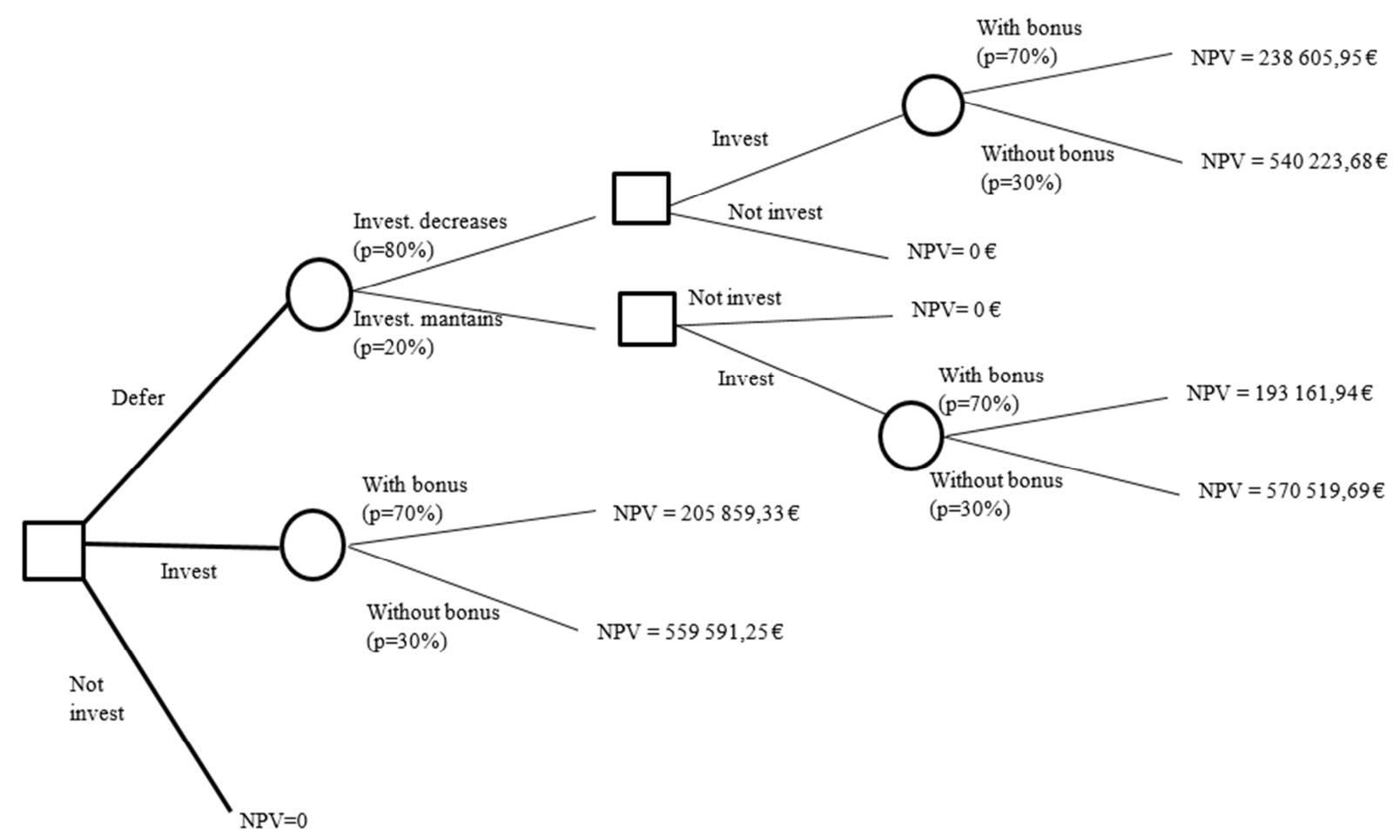

Figure 1. Decision tree for the investment.

Analyzing the decision tree, it is obvious that if the Campus has to pay the tariff without bonus, the NPV increases very much, because the opportunity costs also increase a lot, since the PV system allow to save much more comparing with the bonus tariff. To solve the decision tree, the analysis starts with the right leafs.

For to the rightmost decision nodes, the expected NPV is calculated:

$\mathrm{E}(\mathrm{NPV}) \mid($ Not invest $)=0 €$

$\mathrm{E}(\mathrm{NPV}) \mid($ Defer, the investment decreases and invest $)=$ $238,605.95 \times 0.7+540,223.68 \times 0.3=329,091.27 €$

$\mathrm{E}(\mathrm{NPV}) \mid($ Defer, the investment maintains and invest $)=$ $193,161.94 \times 0.7+570,519.69 \times 0.3=306,369.27 €$

After these calculations, the next decision tree is obtained:

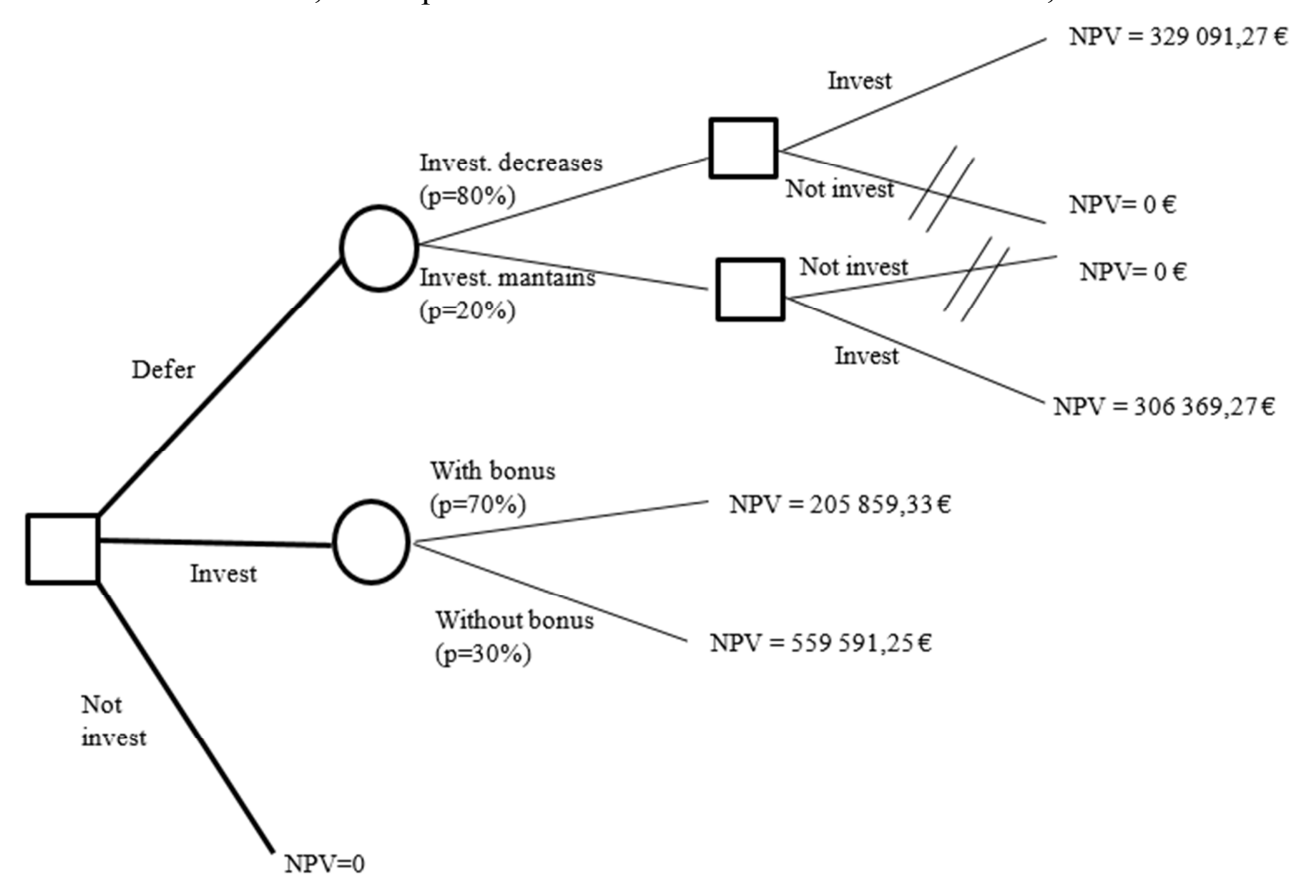

Figure 2. Decision tree for the investment after the first calculations. 
For the rightmost decision nodes, the decision, in each case, is to invest. Proceeding to the next decision node, the expected NPVs are calculated:

$\mathrm{E}(\mathrm{NPV}) \mid($ Not invest $)=0 €$

$\mathrm{E}(\mathrm{NPV}) \mid($ Defer $)=329,091.27 \times 0.8+306,369.27 \times 0.2=$ $324,546.87 €$

$\mathrm{E}(\mathrm{NPV}) \mid($ Invest $)=205,859.33 \times 0.7+559,591.25 \times 0.3=$ $311,978.91 €$

After these calculations, the following tree is obtained:

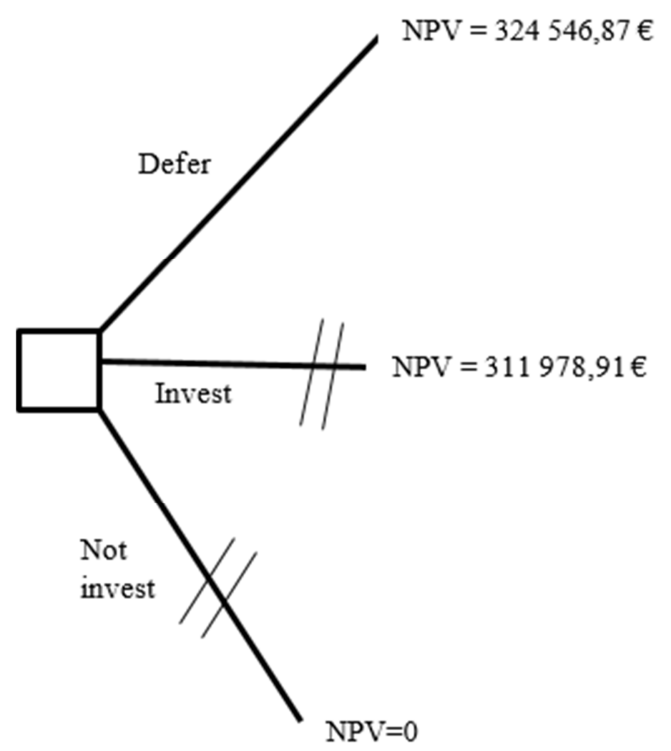

Figure 3. Final decision tree for the investment.

For this decision tree, the decision is to defer the investment, although the NPVs are not too different. The decision may be investing, instead of deferring, if it were considered a lower investment drop or a lower probability of the investment decreasing. However, in any decision node, investing or deferring is always better than not investing.

It is important to refer that, without bonus in the tariff, the payback is much lower, less than 7 years, from the moment of the investment. So, organizations that do not benefit in the tariff of electricity, should consider investing in a PV system for self-consumption, in order to save money in the electricity paid to the network and to help the planet.

The example presented are simple, but it serves to illustrate the utility of decision trees to model sequential decisions when there are sources of uncertainty. Decision trees are simple and they are quite visual, helping to perceive decision sequences over an investment lifetime.

\section{Conclusions}

This work intended to evaluate a UPAC PV system in the Polytechnic Campus of Viseu, using decision trees, which are a real option technique. This idea is related to the fact that, in Portugal, the solar energy still has little use, when Portugal is one of the countries in Europe with more hours of solar incidence.

The analysis of the decision tree has led to the conclusion that the investment is viable, and the time to recover the investment is shorter the higher is the electricity tariff. Considering the fact that the costs investment has a downward trend, the defer option can be taken into account, in spite of the loss of the opportunity costs during the waiting time. On the other hand, Campus enjoys bonus in electricity tariff, which increases the payback period. However, in the absence of bonus, the expected NPV increases and the payback period decreases. The application of the decision trees served the purpose of illustrating the modeling of decisions, when there are sources of uncertainty.

In any case, the interest of investing in a UPAC PV system becomes clear. Thus, the demand of these systems should be greater, both by businesses and individuals. Sunlight is an inexhaustible source of energy and it should be more used for the planet's sustainability, especially in countries like Portugal.

\section{Acknowledgements}

This work is financed by national funds through FCT Fundação para a Ciência e Tecnologia, I. P., under the project UID/Multi/04016/2016. Furthermore we would like to thank the Instituto Politécnico de Viseu and CI\&DETS for their support.

\section{References}

[1] J. A. Monteiro, Master Thesis: Produção Fotovoltaica: Legislação, tarifas, tecnologia necessária e viabilidade económica para a produção numa perspetiva de chave na mão. Faculdade de Engenharia da Universidade do Porto, 2014.

[2] G. E. Mathews and E. H. Mathews, "Household photovoltaics - A worthwhile investment?" 2016 International Conference on the Domestic Use of Energy (DUE), Cape Town, 2016, pp. 1-7. doi: 10.1109/DUE.2016.7466716.

[3] K. T. Yeo and F. Qiu, "The value of management flexibility - a real option approach to investment evaluation." International Journal of Project Management vol. 21, pp. 243-250, 2003.

[4] M. Mancini, R. Sala, D. Tedesco and A. Travaglini, "A real options investment model for the evaluation of wind and photovoltaic plants," 2016 IEEE International Conference on Industrial Engineering and Engineering Management (IEEM), Bali, 2016, pp. 1101-1105. doi: 10.1109/IEEM.2016.7798048.

[5] J. D. Pereira, Master Thesis: Instalações Solares Fotovoltaicas para Autoconsumo: Análise e Perspetivas de Aplicação. Porto: Faculdade de Engenharia da Universidade do Porto, 2016.

[6] Decree-Law no. 153/2014, Diário da República n. ${ }^{\circ}$ 202/2014, Série I de 2014-10-20.

[7] F. Pinto, Ordem Engenheiros, 2015. Obtained from http://www.ordemengenheiros.pt/fotos/dossier_artigo/2015112 0 _filipepinto_7615808675660254a2675c.pdf

[8] H. Barros, Análise de Projectos de Investimentos. Lisboa, Sílabo (5th edition), 2014.

[9] A. Dixit and R. Pindyck, Investment under uncertainty. New Jersey, Princeton University Press, 1993. 
[10] G. Blanco and F. Olsina, "Real Option Valuation of FACTS Investments Based on the Least Square Monte Carlo Method", IEEE Trans. on Power Systems, vol. 26, no. 3, pp. 1389-1398, August 2011.

[11] L. P. Santiago and T. G. Bifano, "Management of R\&D projects under uncertainty: a multidimensional approach to managerial flexibility.”, IEEE Trans. on Eng. Man., vol. 52, no. 2, pp. 269-280, 2005.

[12] S. C. Myers, "Finance theory and finance strategy." Interfaces, vol. 14, no. 1, pp. 126-137, 1984.

[13] G. Cortazar, M. Gravet and J. Urzua, "The valuation of multidimensional American real options using the LSM simulation method." Computers \& Operations Research, vol. 35, pp. 113-129, 2008.

[14] M. Brach and D. Paxson, "A gene to Drug Venture: Poisson Options Analysis.” R\&D Management vol. 31, no. 2, pp. 203214, 2001.

[15] O. Lint and E. Pennings, "An option approach to the new product development process: a case study at Philips Electronics.” R\&D Management, vol. 31, no. 2, pp. 163-172, 2001.

[16] E. Schwartz and C. Zozaya-Gorostiza, "Investment Under Uncertainty in Information Technology: Acquisition and Development Projects." Management Science vol. 49, no. 1, pp. 57-70, 2003.

[17] J. Lee and D. Paxson, "Valuation of R\&D real American sequential exchange options." R\&D Management, vol. 21, no. 2, pp. 191-201, 2001.

[18] J. Fialho, PhD Thesis: Avaliação de Projetos de Investigação e
Desenvolvimento na Área das Telecomunicações, Faculdade de Economia da Universidade de Coimbra, 2013.

[19] A. Gomes, A. P. Pinto and J. Fialho, "Avaliação Económica de um Sistema de Produção Fotovoltaico para Autoconsumo", Fronteiras: Journal of Social, Technological and Environmental Science, v. 6, n. 3, pp. 83-98, 2017.

[20] REN - Redes Energéticas Nacionais, Síntese anual 2011 - 2015 - REN. Obtido de REN - Redes Energéticas Nacionais, 2015. Obtained from http://www.mercado.ren.pt/PT/Electr/InfoMercado/PressReleas es/BibInfAnual/MercadoEletricidadeSinteseAnual2011_2015.p df

[21] ERSE - Entidade Reguladora dos Serviços Energéticos, 2016, Obtained from http://www.erse.pt/pt/glossario/Paginas/glossario.aspx?folder= baeaae46-4f3f-401d-91ff-668518dd41e8

[22] E. Franco, N. Monteiro and L. Machado. Autoconsumo fotovoltaico - exemplo de dimensionamento e estudo económico. Renováveis Magazine, 2015. Obtained from http://www.renovaveismagazine.pt/?p=10050

[23] ERSE - Entidade Reguladora dos Serviços Energéticos, Parâmetros de Regulação para o Período 2015-2017. Lisboa: Entidade Reguladora dos Serviços Energéticos, 2014.

[24] Portal da Eneriga, 2017. Obtained from https://www.portalenergia.com/preco-paineis-solares-fotovoltaicos-baixo/

[25] ERSE - Entidade Reguladora dos Serviços Energéticos, 2018, Obtained

from http://www.erse.pt/pt/electricidade/tarifaseprecos/2018/Pagina s/default.aspx 